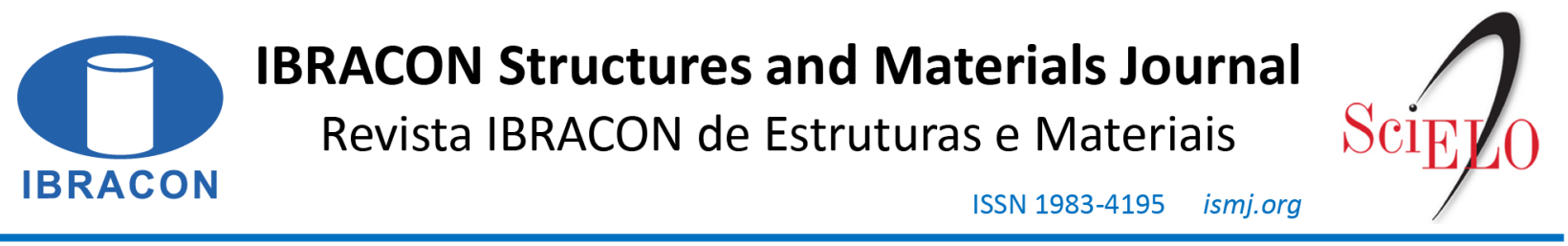

ORIGINAL ARTICLE

\title{
Numerical investigation on slim floors: comparative analysis of ASB and CoSFB typologies
}

\section{Investigação numérica sobre slim floors: análise comparativa das tipologias ASB e COSFB}

\author{
Tainá Mascarenhas Borghi ${ }^{\mathrm{a}}$ \\ Lucas Antônio Morais Oliveira ${ }^{\mathrm{a}}$ (1) \\ Ana Lucia Homce de Cresce El Debs ${ }^{\mathrm{a}}$ (D)
}

${ }^{a}$ Universidade São Paulo - USP, Escola de Engenharia de São Carlos, Departamento de Engenharia de Estruturas, São Carlos, SP, Brasil

Received 26 June 2020

Accepted 24 November 2020

\begin{abstract}
Innovative composite structures have been intensively studied towards meeting the demands of civil construction. An example of such structures is slim floor, comprised of concrete or composite slabs positioned at the height of steel beams, reducing the total height of the floor. In Brazil, studies on this system are still in early stages, and due to the lack of both experience and national normative codes, it is hardly used in civil construction. Given the possible combinations between concrete slabs and steel beams, the system exhibits different typologies. This article reports a numerical investigation on two typologies of slim floor, namely Asymmetric Slimflor Beam (ASB), composed of an asymmetric I beam, and Composite Slim-Floor Beam (CoSFB), comprised of an asymmetric beam with small openings at the top of its web. Nonlinear numerical models of ASB and CoSFB typologies were developed by Finite Elementbased software ABAQUS ${ }^{\circledR}$. The models were calibrated with the use of experimental studies from the literature, and showed high accuracy and good results. After calibration, the materials properties and geometric dimensions of the models, such as height and thickness, were standardized for a comparison of the typologies. The comparative analysis showed the particular characteristics of CoSFB promoted higher stiffness and flexural capacity compared to ASB, and a parametric analysis evaluated the influence of steel and concrete parameters on the flexural behavior of the typologies. The parametric study revealed the steel parameters exerted a more substantial influence on the slim floors behavior than the concrete ones.
\end{abstract}

Keywords: composite structures, slim floor, Asymmetric Slimflor Beam (ASB), Composite Slim-Floor Beam (CoSFB), numerical analysis. Resumo: Estruturas mistas inovadoras vêm sendo intensamente estudadas para atender as demandas da
construção civil. Um exemplo de tais estruturas é o piso misto de pequena altura, composto por lajes de
concreto ou mistas, posicionadas na altura de vigas de aço, reduzindo a altura total do piso. No Brasil,
os estudos sobre esse sistema ainda são iniciais e, devido à falta de experiência e de códigos normativos
nacionais, ele é pouco utilizado na construção civil brasileira. Devido às inúmeras combinações
possíveis entre lajes e vigas de aço, o sistema apresenta diferentes tipologias. Este artigo apresenta uma
investigação numérica sobre duas tipologias de piso misto de pequena altura, sendo elas Asymmetric
Slimflor Beam (ASB), composta por uma viga I assimétrica, e Composite Slim-Floor Beam (CoSFB),
composta por uma viga assimétrica com pequenas aberturas na parte superior da alma. Uma análise
numérica não linear em elementos finitos foi realizada com o software ABAQUS, e os modelos
numéricos das tipologias ASB e CoSFB foram calibrados a partir de resultados experimentais da
literatura. Após a calibração, os modelos foram padronizados de acordo com as propriedades dos
materiais e dimensões geométricas, como altura e espessura, para a comparação das tipologias. Uma
análise paramétrica avaliou a influência de parâmetros do aço e do concreto no comportamento à flexão
dessas tipologias. A calibração numérica apresentou alta precisão e bons resultados e a análise numérica
comparativa mostrou que as caracteristicas particulares do CoSFB promoveram maior rigidez e

Corresponding author: Tainá Mascarenhas Borghi. E-mail: tainaborghi@usp.br

Financial support: Conselho Nacional de Desenvolvimento Científico e Tecnológico (CNPq) (Grant number 131455/2018-4) and Coordenação de Aperfeiçoamento de Pessoal de Nível Superior - Brasil (CAPES) - Finance Code 001 and (Grant number 2019/03513-5) - São Paulo Research Foundation (FAPESP).

Conflict of interest: Nothing to declare.

This is an Open Access article distributed under the terms of the Creative Commons Attribution License, which permits unrestricted use, distribution, and reproduction in any medium, provided the original work is properly cited. 
capacidade de flexão em relação ao ASB. O estudo paramétrico revelou que os parâmetros do aço exerceram maior influência que os parâmetros do concreto.

Palavras-chave: estruturas mistas, piso misto de pequena altura, Asymmetric Slimflor Beam (ASB); Composite Slim-Floor Beam (CoSFB), análise numérica.

How to cite: T. M. Borghi, L. A. M. Oliveira, and A. L. H. C. El Debs, "Numerical investigation on slim floors: comparative analysis of ASB and CoSFB typologies," Rev. IBRACON Estrut. Mater., vol. 14, no. 4, e14411, 2021, https://doi.org/10.1590/S1983-41952021000400011

\section{INTRODUCTION}

Studies on composite structures have substantially increased in the global scenario, since such structures benefit from both high tensile strength of the steel and compressive strength of the concrete [1], meeting the current demands for more efficient civil industry and economical and fast construction. Other qualities, e.g., possible reductions in selfweight, ability to overcome large spans with no shoring, buckling attenuation, and more effective fire and corrosion protection, are relevant in comparison to reinforced concrete or steel structures.

Slim floor offers such benefits, since it is composed of a steel beam, concrete or composite slab and shear connections, resembling composite beams. Besides, it reduces the total height of the floor by coupling the concrete slab at the height of the steel beam [2]. Since concrete encases the steel beam, the ultimate capacity and stiffness in normal and fire situations increase, and local instabilities, typical of steel structures, decrease. In addition, slim floor enables a range of different compositions, varying the type of slab and beam employed, or the position and type of shear connections [2].

Among such possibilities from variations in the steel profile, the most studied and used internationally are Asymmetric Slimflor Beam (ASB), Composite Slim Floor Beam (CoSFB), Deltabeam, and Shallow Cellular Composite Floor Beam (SCCFB) (see Figure 1 - schematic models) [3].

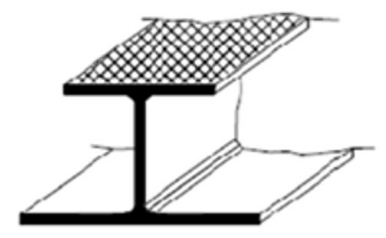

(a) Asymmetric Slimflor Beam (ASB)

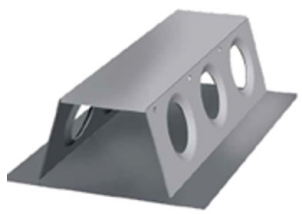

(c) Deltabeam

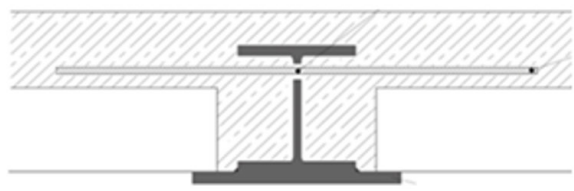

(b) Composite Slim Floor Beam (CoSFB)

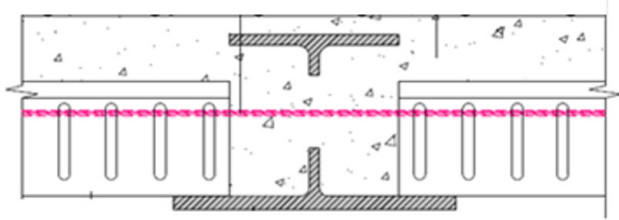

(d) Shallow Cellular Composite Floor Beam (SCCFB)

Figure 1. Slim floor typologies.

Studies on the slim floor system are still incipient in Brazil and, due to the lack of normative codes, it is hardly applied for construction. Furthermore, most research has focused on the behavior of only one typology. This study aims to contribute with the dissemination of knowledge on slim floor through a numerical investigation of the Asymmetric Slimflor Beam (ASB) and Composite Slim Floor Beam (CoSFB). It evaluates the flexural behavior of the two typologies, starting from the models calibration, standardization of the typologies according to the geometric dimensions and properties of the materials for a comparison, and ending with a parametric study.

ASB is composed of a type "I" steel beam with bottom flange width larger than that of top flange. Grooves on the external face of the top flange aim to improve the connection between steel and concrete [4]. CoSFB consists of a symmetric "I" steel beam with small openings at the top of the web and a steel plate wider than the flange welded to the bottom [5]. Figures 2a and 2b, respectively, show the configurations of ASB and its real application in Chasse Church (Germany) [6] and CoSFB and its real application in Dillingen a.d. Donau (Germany) [7]. 

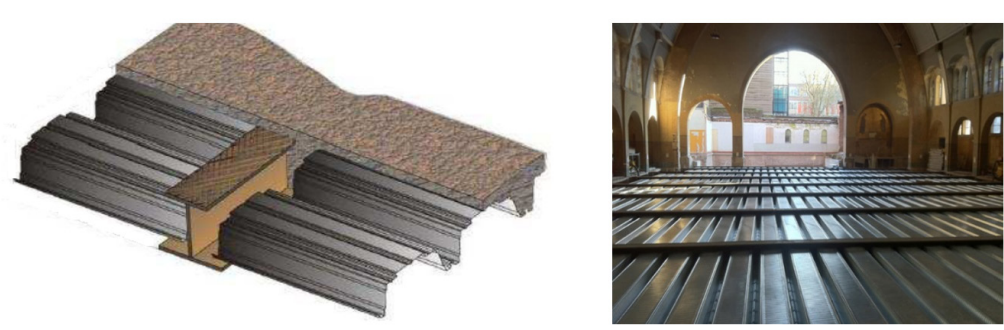

(a) Asymmetric Slimflor Beam (ASB)

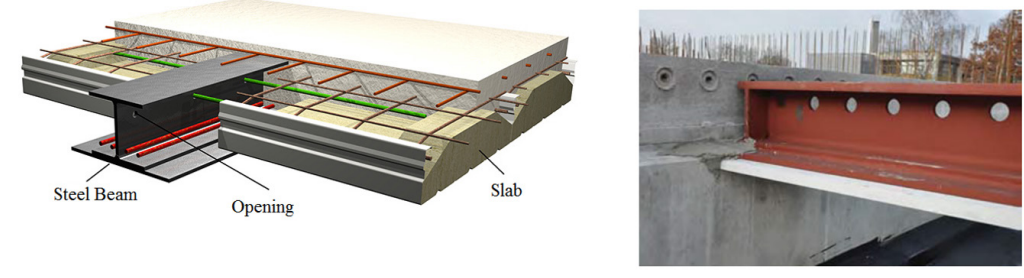

(b) Composite Slim-Floor Beam (CoSFB)

Figure 2. Slim floor.

The ASB was chosen for analysis in the present study because it is the most applied typology in construction worldwide, presenting a proposal for design and study of the behavior already consolidated [8], [9], [4]. Conversely, CoSFB is a new promising typology with some successful applications in Europe [7]. Many studies on the two typologies have been developed since the end of the last century and will be covered in the following section.

\section{STATE OF ART}

The main studies on slim floor began with Mullet [8], Mullet and Lawson [9], and Lawson et al. [4], who experimentally investigated Asymmetric Slimflor Beam (ASB) and proposed a design method, according to BS 5950 [10]. Bailey [11] analyzed the behavior of ASB under fire and developed software that predicted its structural behavior in this situation. Through numerical analysis, Mäkeläinen and Ma [12] demonstrated the excellent performance of the typology under those circumstances.

Paes [13] also conducted a numerical analysis and established design recommendations for ASB's ultimate capacity and in-service conditions. The author developed numerical models based on studies of Lawson et al. [4] and Leskelä and Hopia [14] and obtained compatible results. Rackham et al. [15] published guidelines for the design of ASB with concrete hollow core slab, and a calculation procedure based on BS 5950 [10] was established for checking the design in the ultimate and in-service conditions, profile instabilities, shear, torsion and bending resistance. A theoretical study developed by Ahmed and Tsavdaridis [16] provided a summary of the slim floor typologies, characteristics, and design formulations. All above-cited authors contributed to the current design recommendations, presented by Barros [17].

Studies on CoSFB started with Braun et al. [18], and Hechler et al. [5], considered precursors in the theme. They performed push-out and bending tests and evaluated shear, bending, vibration, and deformation, which revealed increases of $100 \%$ in load capacity and $150 \%$ in stiffness compared to usual composite beams. Sheehan et al. [19] analyzed the degree of shear connection of steel bars and their resistance capacity through shear and bending tests and observed the number of steel bars that passed the beam openings directly influenced the system's flexural strength. Baldassino et al. [20] experimentally evaluated CoSFB's in-service behavior, and observed the final response was affected by concrete's curing time and creep effects.

Regarding shear connectors on the slim floor, initially only stud bolts welded to the top flange of the profile were used (Figure 3a). De Nardin and El Debs [2] showed such connectors could also be welded to the bottom flange (Figure $3 \mathrm{~b}$ ), to both flanges (Figure 3c), or to the web (Figure 3d), with the former solution providing the best behavior.

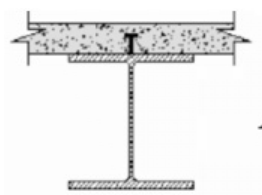

a)

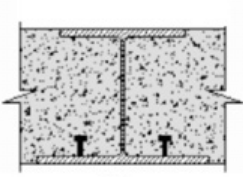

b)

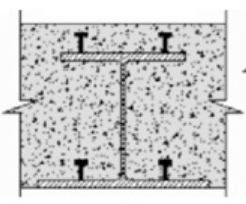

c)

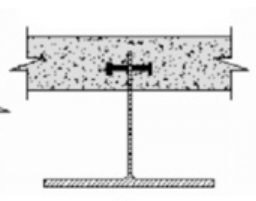

d)

Figure 3. Position of stud bolt. 
The shear connections currently used on slim floor have been innovated, and those with steel bars passing through the profile openings are now the most studied (see Ju et al. [21], Leskela et al. [22], Lam et al. [23], Huo and D'Mello [24] and Chen and Limazie [25]). When in contact with concrete, such bars guarantee the shear connection, transferring the longitudinal shear force between the concrete slab and steel beam [26].

Numerical simulations consume fewer financial, human, and time resources, when compared to experimental tests. However, model calibrations require the use of experimental results from previous tests, which enable the identification of the structure's global response and the parameters that affect it. They imply some tweaks in the numerical model for the matching of numerical and experimental results. Therefore, experimental results of Lawson et al. [4] were employed for ASB, whereas those of Hechler et al. [5] were applied for CoSFB.

The present numerical FE analysis was based on several numerical studies of slim floor, which indicated the most appropriate element type, constitutive relations, mesh and contact interactions (see Rocha [26], Maraveas et al. [27], Leskela et al. [22], Hechler et al. [5], Limazie and Chen [28], Kochem and De Nardin [29], Minhaneli [30] and Soares [31]).

\section{NUMERICAL INVESTIGATION}

The numerical investigation was divided into the following three stages: i) calibrations of ASB and CoSFB, ii) standardization of the geometries and materials properties for the comparison of the two models, and iii) a parametric study that evaluated the influence of concrete strength, concrete topping above the steel beam, strength of steel beams and bottom flange thickness on the flexural behavior. ABAQUS ${ }^{\circledR}$ Software was used for the numerical simulation.

In the first stage, the characteristics of the experimental study for the calibration were inserted. The geometrical characteristics of ASB followed a test conducted by Lawson et al. [4] (Figure 4), with 280 ASB 100 profile and composite slab used in the numerical simulation. The reinforcement consisted of $11 \varnothing 16 \mathrm{~mm}$ transversal bars. For the sake of simplification, the steel deck was not modelled, since its behavior does not affect the flexural response, and its contribution can be disregarded [3]. However, the concrete slab was modeled as if there were a steel deck, due to the influence of the volume of concrete on many parameters, such as system's stiffness, resistance, ductility and collapse mode.

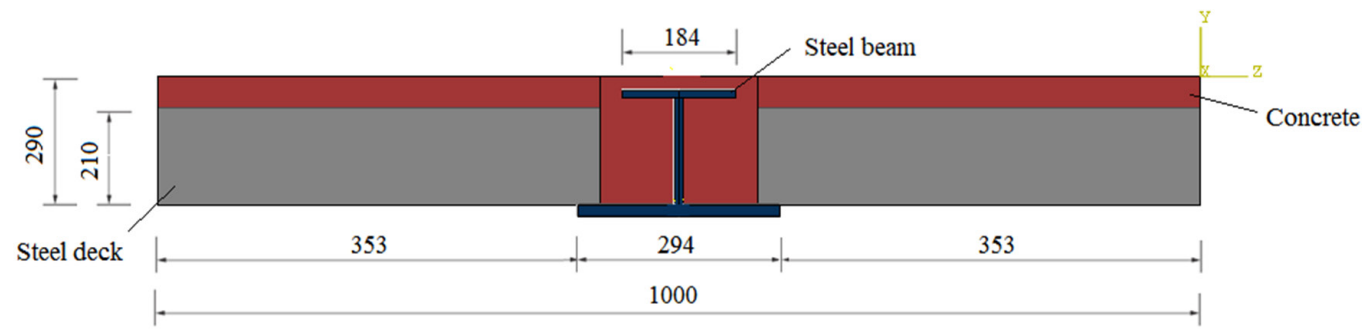

(a) Cross-section

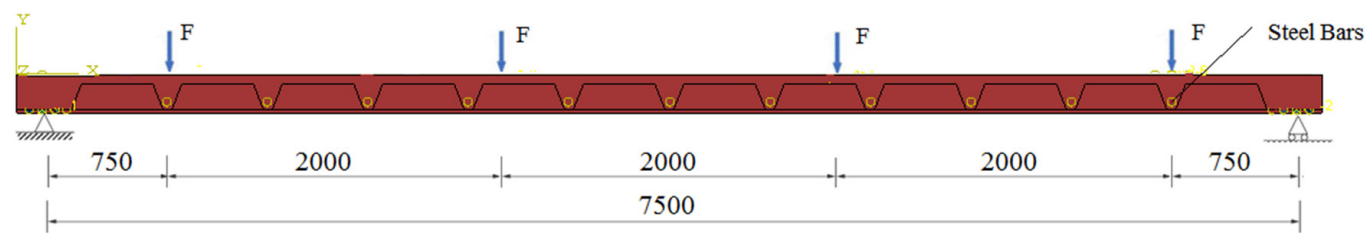

(b) Longitudinal details

Figure 4. Geometrical characteristics of Lawson et al. [4] test (measurements in mm).

Figure 5 shows the geometrical characteristics of CoSFB, according to Hechler et al. [5]. HEM 220 steel profile and composite slab were used and filled with rock wool. The reinforcement consisted of $\varnothing 16 \mathrm{~mm}$ transversal bars passing through each opening. Since it is a wholly filled slab, its simulation as only concrete was adopted. 


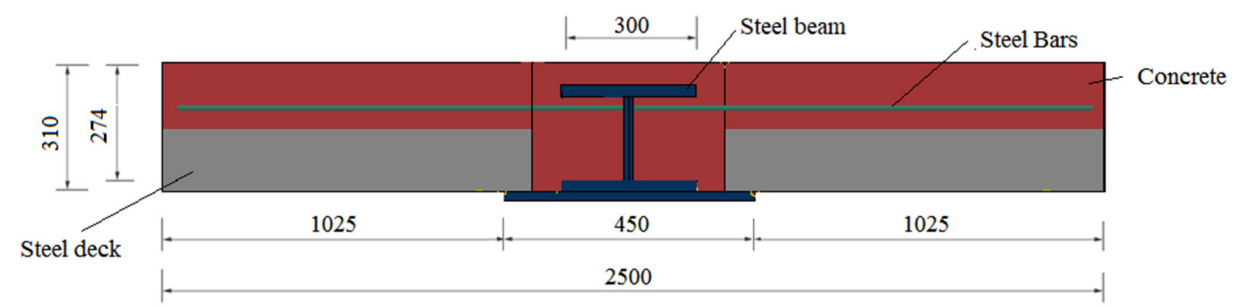

(a) Cross-section

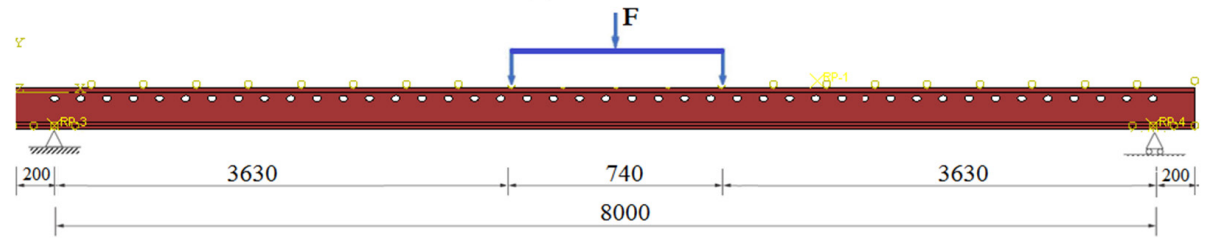

(b) Longitudinal details

Figure 5. Geometrical characteristics of Hechler et al. [5] test (measurements in mm).

The materials properties (Table 1) were taken from the experimental studies [4], [5] used for the calibration.

Table 1. Materials properties.

\begin{tabular}{|c|c|c|c|c|c|}
\hline & & \multicolumn{2}{|c|}{ ASB } & \multicolumn{2}{|c|}{ CoSFB } \\
\hline \multirow{4}{*}{ Beam } & Span (m) & \multicolumn{2}{|c|}{7.5} & \multicolumn{2}{|c|}{8.0} \\
\hline & \multirow{2}{*}{ Steel (MPa) } & $f_{y}$ & $f_{u}$ & $f_{y}$ & $f_{u}$ \\
\hline & & 405.7 & 430 & 500 & 516 \\
\hline & $\mathrm{E}(\mathrm{MPa})$ & \multicolumn{2}{|c|}{200000} & \multicolumn{2}{|c|}{190000} \\
\hline \multirow{5}{*}{ Composite Slab } & Width (m) & \multicolumn{2}{|c|}{1.0} & \multicolumn{2}{|c|}{2.5} \\
\hline & Height (m) & \multicolumn{2}{|c|}{0.29} & \multicolumn{2}{|c|}{0.31} \\
\hline & $\mathrm{E}(\mathrm{MPa})$ & \multicolumn{2}{|c|}{33873} & \multicolumn{2}{|c|}{32000} \\
\hline & $\mathrm{f}_{\mathrm{c}} \mathrm{f}_{\mathrm{ck}}(\mathrm{MPa})$ & \multicolumn{2}{|c|}{34} & \multicolumn{2}{|c|}{30.1} \\
\hline & $\mathrm{f}_{\mathrm{t}} \mathrm{f}_{\mathrm{t}}(\mathrm{MPa})$ & \multicolumn{2}{|c|}{3.15} & \multicolumn{2}{|c|}{2.9} \\
\hline \multirow{3}{*}{ Rebars } & Lenght (m) & \multicolumn{2}{|c|}{0.43} & \multicolumn{2}{|c|}{2.4} \\
\hline & $\mathrm{f}_{\mathrm{y}} \mathrm{f}_{\mathrm{t}}(\mathrm{MPa})$ & \multicolumn{2}{|c|}{500} & \multicolumn{2}{|c|}{500} \\
\hline & $\mathrm{E}(\mathrm{MPa})$ & \multicolumn{2}{|c|}{210000} & \multicolumn{2}{|c|}{210000} \\
\hline
\end{tabular}

In the calibration phase, the boundary and loading conditions were based on experimental tests. The former was a simply supported beam, and the load was applied in an incremental force. Lawson et al. [4] applied four loads to the beam, as shown in Figure 6a, whereas Hechler et al. [5] applied load centrally to the slab (Figure 6b).

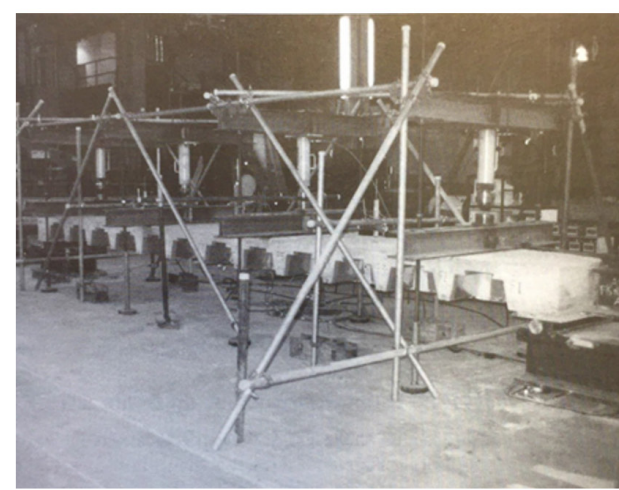

(a) Asymmetric Slimflor Beam (ASB)

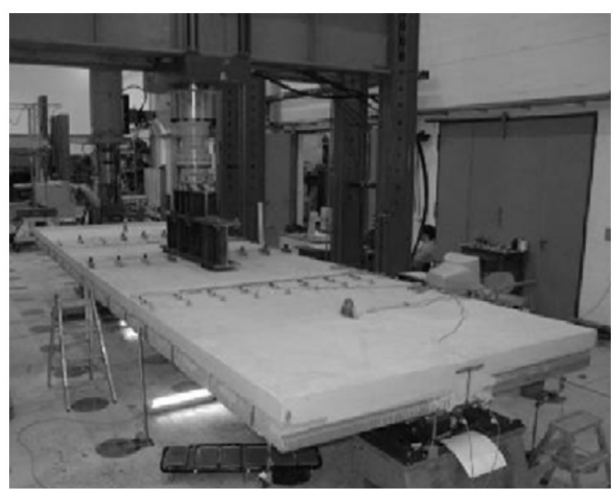

(b) Composite Slim-Floor Beam (CoSFB)

Figure 6. Loading condition of experimental tests. 
After calibration, the models were standardized for basic geometric dimensions and materials properties, towards a more reliable comparison of the structural behavior of the typologies. The dimensions standardized for the profile were web height, web and top flange thickness and bottom flange area (Figure 7a, 7b), and height, width, and length were uniform for the slab (Figure 7c). The reinforcement consisted of Ø16 mm transversal bars in both models.

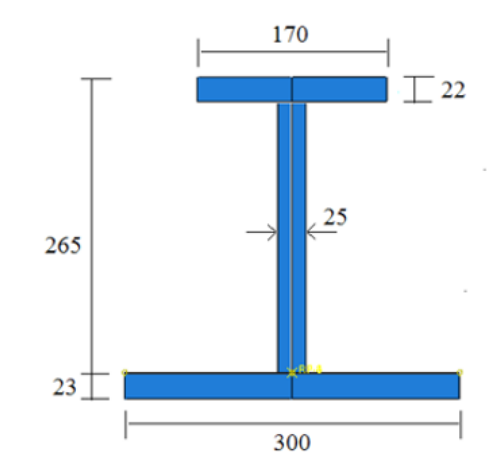

(a) Asymmetric Slimflor Beam (ASB)



(b) Composite Slim-Floor Beam (CoSFB)

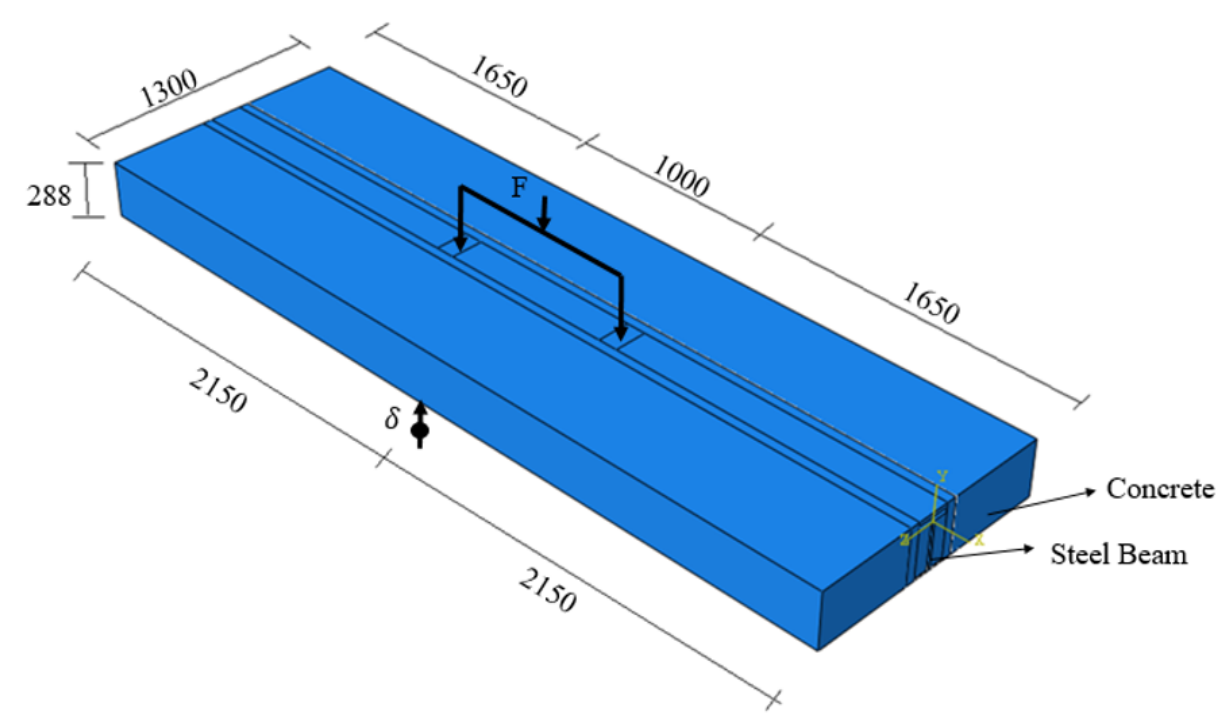

(c) Slab standardized

Figure 7. Geometric dimensions standardized (mm).

Composite Slim-Floor Beam is composed of a profile with an additional plate welded to its bottom flange. Therefore, the thickness of the bottom flange is given by the sum of the thicknesses of the two components. Towards standardizing this parameter of ASB and CoSFB, and considering the minimum thickness of the plate is $15 \mathrm{~mm}$, the value of $10 \mathrm{~mm}$ was used for the bottom flange of the profile for the obtaining of the same inertias of the steel profile. Standardized profiles are not commercial, and those dimensions were used only for comparison purposes. Table 2 shows the values of the materials properties [3].

Table 2. Materials properties.

\begin{tabular}{cccccc}
\hline Components & $\mathbf{f}_{\mathbf{y}}(\mathbf{M P a})$ & $\mathbf{f}_{\mathbf{u}}(\mathbf{M P a})$ & $\mathbf{E}(\mathbf{M P a})$ & $\mathbf{f}_{\mathbf{c m}}(\mathbf{M P a})$ & $\mathbf{f}_{\mathbf{t}}(\mathbf{M P a})$ \\
\hline Steel profile & 430 & 550 & 200000 & - & - \\
\hline Concrete & - & - & 32000 & 30 & 2.9 \\
\hline Rebars & 500 & - & 210000 & - & - \\
\hline
\end{tabular}


Boundary and loading conditions were also the same for both typologies in the second phase. A simply supported beam was considered, and the loading was an $80 \mathrm{~mm}$ displacement incrementally applied at two points, as in the fourpoint flexural test (Figure 8).

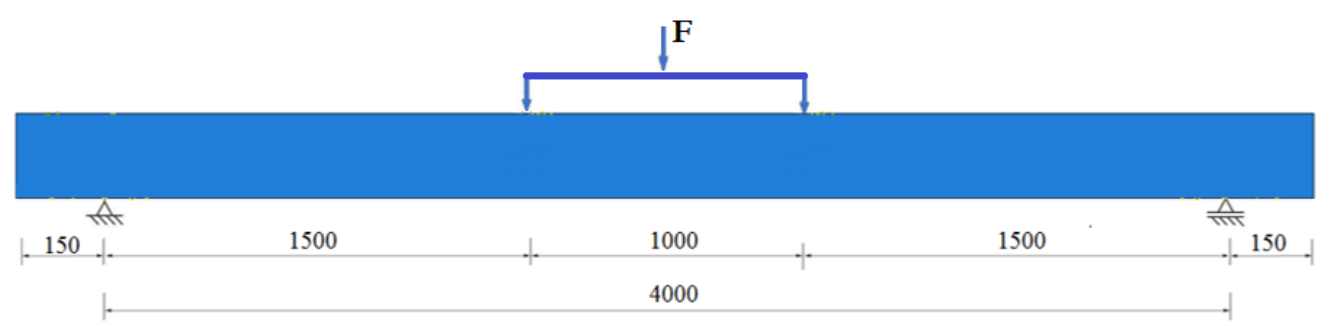

Figure 8. Boundary and loading condition of standardized model (measurements in $\mathrm{mm}$ ).

Pre-processing parameters, such as element type and constitutive relations, defined for the calibration phase were maintained for the standardization phase.

\section{Element types}

A finite element must be chosen in such a way it adequately represents the behavior of each structural component. C3D8R, an eight-node three-dimensional solid element with reduced integration, was used for the concrete slab modelling. However, solid elements require a good mesh refinement for the obtaining of representative solutions, hence, high computational costs. For this reason and according to studies of Rocha [26], Limazie and Chen [28], Kochem and De Nardin [29], Minhaneli [30] and Soares [31], shell element S4R, of four-node of 6-degree freedom and reduced integration, is adequate for the steel profile simulation. The modelling employed two-node three-dimensional beam element B31 for the reinforcement bars. Figure 9 shows the finite elements used in all stages.

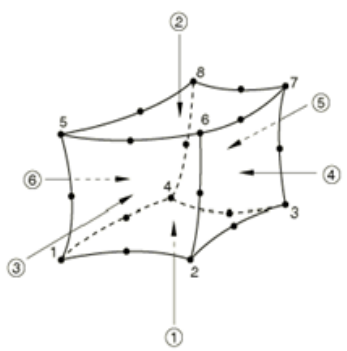

Sólido C3D8R

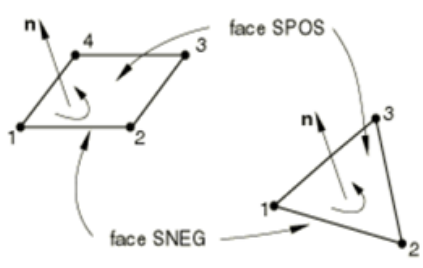

Shell S4R

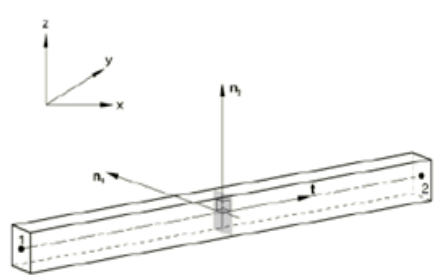

Beam B31

Figure 9. Element types (FE) used.

\section{Materials Constitutive Relations}

The numerical simulation considered the nonlinear behavior of the materials. Therefore, the constitutive models that represent this nonlinearity were defined. According to the study of Kochem and De Nardin [29], the model of Sherbourne and Bahaari [32] can represent the nonlinear behavior of the steel profile, and the perfect elastoplastic model is applicable for the representation of the reinforcing bar. Figure 10 shows both models.

Concrete Damaged Plasticity (CDP) was used for the representation of concrete nonlinearities. This model admits two failure mechanisms, namely tensile rupture and compression crushing, and employs a damage variable to represent the loss of concrete stiffness [27]. The use of CDP in ABAQUS® required the definition of some parameters. The first was dilation angle, which measures the slope of the plastic potential for high confinement stresses - low values are related to concretes of fragile behavior, whereas high ones represent a ductile behavior. Another parameter is flow potential eccentricity, defined as a form assumed by the flow surface, usually a hyperbola of 0.1 default value [33]. 


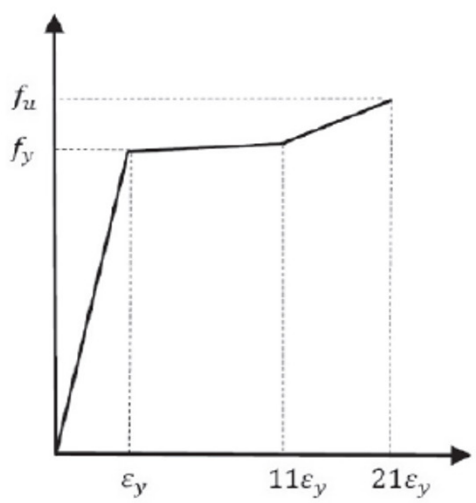

(a) Steel profile

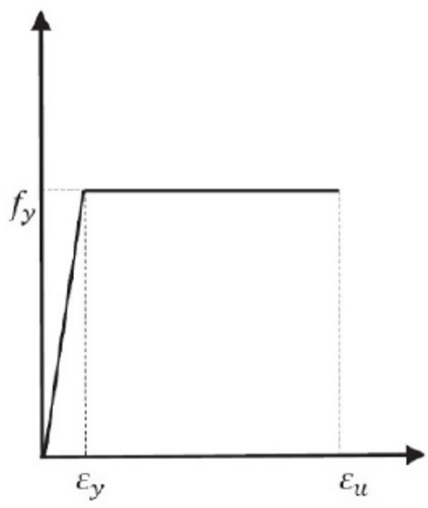

(b) Reinforced bars

Figure 10. Constitutive models adopted for steel profile and bars.

The biaxial/uniaxial compressive strength ratio was adopted for the description of the point at which concrete fails due to biaxial compression (1.16 default value). The fourth parameter determined was ratio of the distances between the hydrostatic axis and compression meridian and tension meridian $(\mathrm{Kc})$, which defines the shape of the concrete failure surface (the default value in ABAQUS ${ }^{\circledR}$ is 0.6667 ). Viscosity repairs convergence difficulties when the model shows degradation of stiffness [33]. Table 3 displays the values of the parameters.

Table 3. Parameters of Concrete Damaged Plasticity.

\begin{tabular}{ccc}
\hline Parameter & Value \\
\hline Dilation angle & $36^{\circ}$ \\
\hline Eccentricity & 0.1 \\
\hline $\mathrm{f}_{\mathrm{b} 0} / \mathrm{f}_{\mathrm{c} 0}$ & 1.16 \\
\hline $\mathrm{Kc}$ & 0.6667 \\
\hline Viscosity & 0.0001 \\
\hline
\end{tabular}

The stress-strain relationship must be considered for a proper choice of a model that represents the behavior of concrete under tension and compression. In this study, the model developed by Carreira and Chu [34] represents the concrete compression behavior; it considers the softening of the concrete in the compression and is based on the limits of stress and strain. The stress-strain relation is given by Equations 1 and 2 and shown in Figure $11 \mathrm{a}$ for $\mathrm{f}_{\mathrm{cm}}=30 \mathrm{MPa}$.

$\sigma_{\mathrm{c}}=\mathrm{f}_{\mathrm{cm}} \frac{\beta\left(\varepsilon / \varepsilon_{\mathrm{c}}^{\prime}\right)}{\beta-1+\left(\varepsilon / \varepsilon_{\mathrm{c}}^{\prime}\right)^{\beta}}$

$$
\beta=\frac{1}{1-\frac{f_{c m}}{\varepsilon_{c}^{\prime} E_{c}}}
$$

The model designed by Polak and Genikomsou [35] represents the concrete tension behavior, whose stress-strain relationship under tension is linear-elastic up to the limit of its strength. After the crack opening, the stress-strain curve is characterized by a loss of stiffness, as shown in Figure $11 \mathrm{~b}$, for $\mathrm{f}_{t}^{\prime}=2.9 \mathrm{MPa}$. The mathematical formulation of the tension and compression behavior of the concrete used in CDP is provided in Ribeiro et al. [33]. 


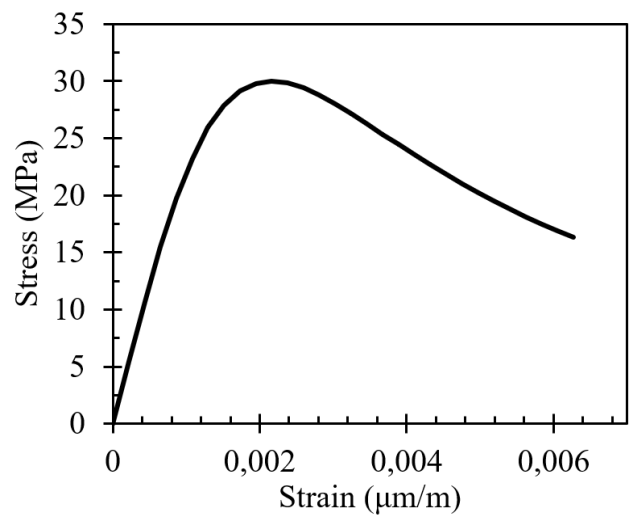

(a) Compression

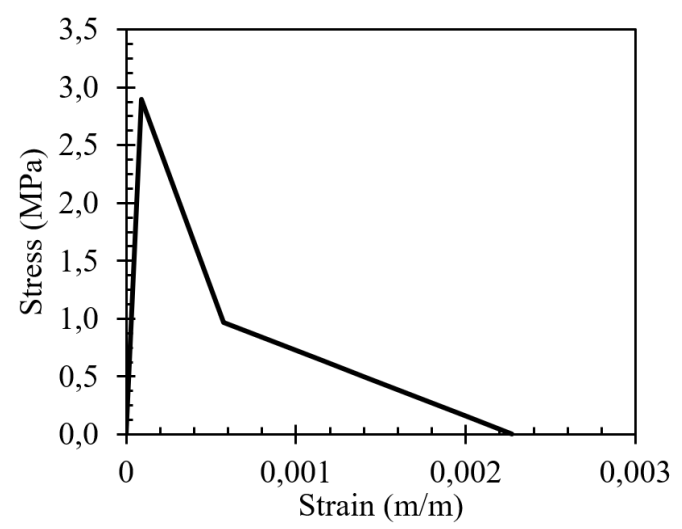

(b) Tension

Figure 11. Stress-Strain curve for concrete.

CDP also enables the definition of damage variables, which represent the degradation of the concrete stiffness under concentrated or cyclic loads. The adoption of the compression damage variable was based on Birtel and Mark [36] (Equation 3) and is shown in Figure 12a, and tension damage was given by the model of Pavlović et al. [37] (Equation 4), shown in Figure 12b.

$\mathrm{d}_{\mathrm{c}}=1-\frac{\sigma_{\mathrm{c}} \mathrm{E}_{\mathrm{c}}^{-1}}{\varepsilon_{\mathrm{c}}^{\mathrm{pl}}\left(\frac{1}{\mathrm{~b}_{\mathrm{c}}}-1\right)+\sigma_{\mathrm{c}} \mathrm{E}_{\mathrm{c}}^{-1}}$

$\mathrm{d}_{\mathrm{t}}=1-\frac{\sigma_{\mathrm{t}}}{\mathrm{ft}}$

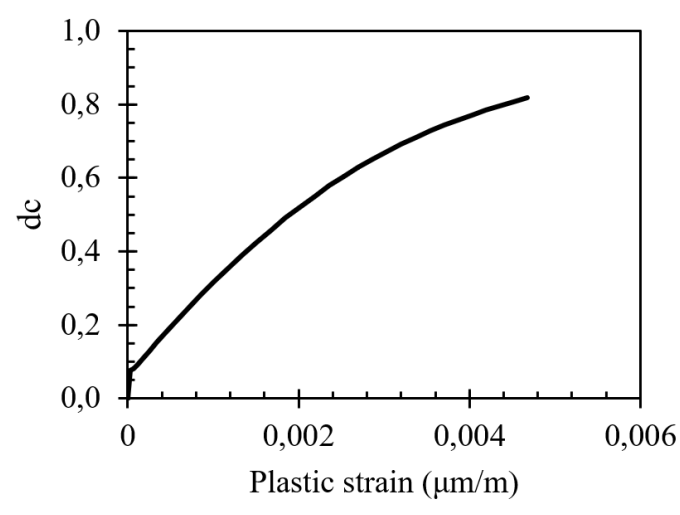

(a) Compression damage

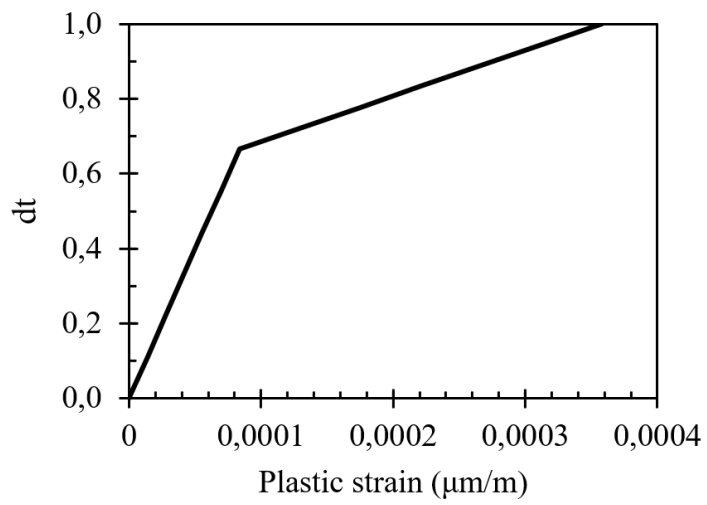

(b) Tension damage

Figure 12. Damage curve for concrete.

\section{Contact modeling}

Apart from materials nonlinearities, this numerical model requires the definition of contact nonlinearities for ensuring both concrete slab and steel profile exhibit a composite behavior. Effective tools must be chosen for the interaction between steel profile and concrete slab, and reinforcing bars and concrete slab. Figure 13 shows such contacts [3]. 


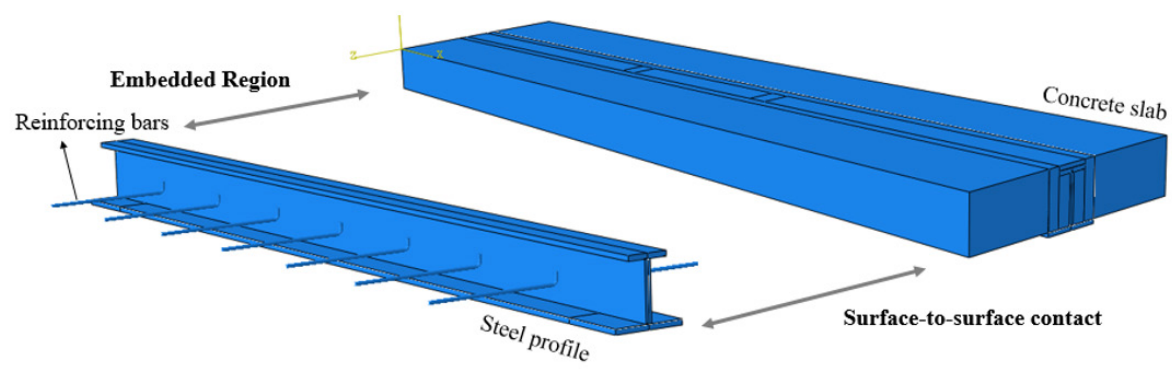

(a) Asymmetric Slim-floor Beam (ASB)

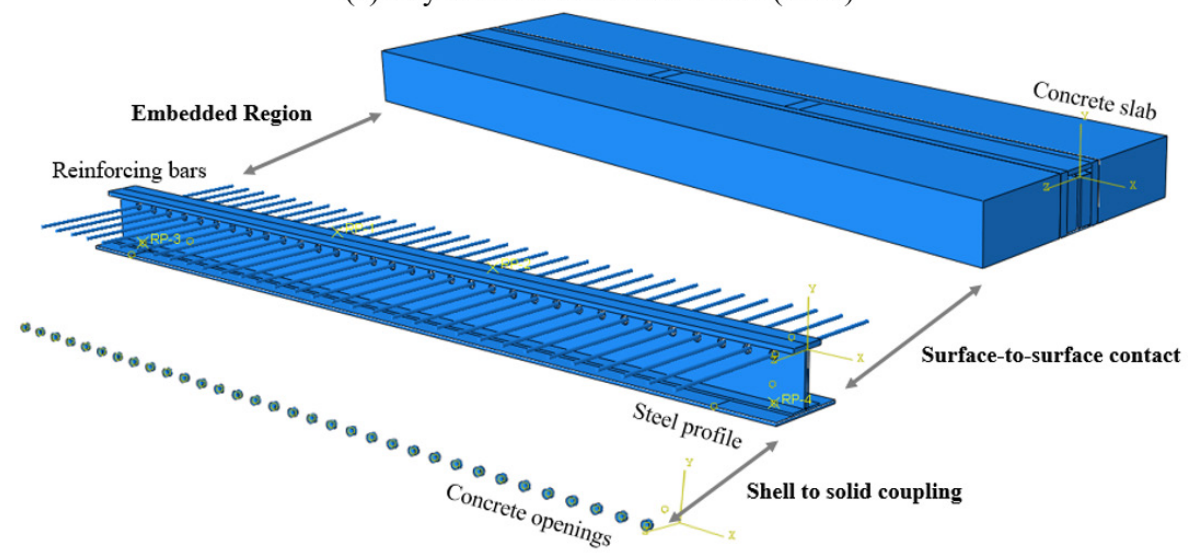

(b) Composite Slim-Floor Beam (CoSFB)

Figure 13. Component contacts.

The connection between reinforcing bars and concrete slab was given by the "Embedded region" command, simulating the adhesion of reinforced concrete with restrictions on a body embedded in another one. "Surface-to-surface contact" interaction tool was used for the contact between the steel profile and the concrete slab. The normal behavior was defined as "Hard contact", according to which a penetration between surfaces is considered imperceptible, and the tangential behavior, with the "Penalty" formulation, enabled a relative movement of the surfaces with a 0.3 coefficient of friction. Despite the presence of grooves on the top flange of the profile, the use of a different friction coefficient does not influence the results of the flexural behavior; therefore, the friction coefficient used was the same for all contacts between profile and concrete [27].

Regarding CoSFB, the contact between the concrete that passes through the openings and the steel profile was promoted by the "Shell to solid coupling" tool. This command connects shell elements to solid ones, coupling the displacement and rotation of the shell nodes to the nearest solid nodes, considered a complete interaction. The connection between rebars and concrete in the web openings was the "Embedded region".

\section{Model meshing}

Refinement and regularization of elements are two critical factors in the definition of a model's mesh. Towards ensuring the dimensions of each part were equal, a $50 \mathrm{~mm} \times 50 \mathrm{~mm}$ x $50 \mathrm{~mm}$ mesh was created in the concrete slabs and discretized into $35 \mathrm{~mm} \times 35 \mathrm{~mm}$ elements for the steel profiles. The reinforcements mesh was $10 \mathrm{~mm}$. No improvement was observed in the results for more refined mesh values; therefore, they were considered ideal meshes. Figures 14a and 14b show the meshes of the structures for the calibration and standardization phases, respectively. 

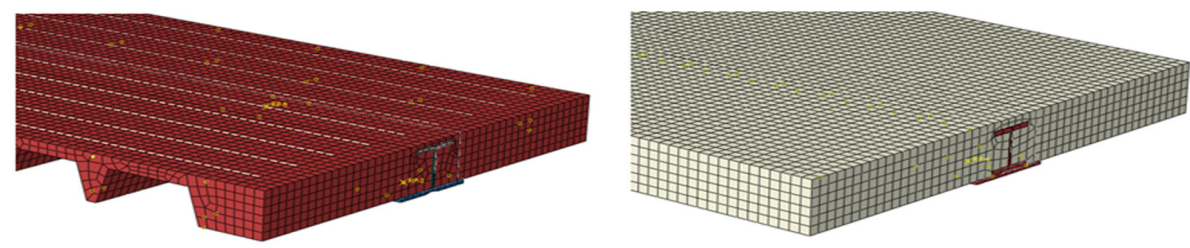

(a) Calibration
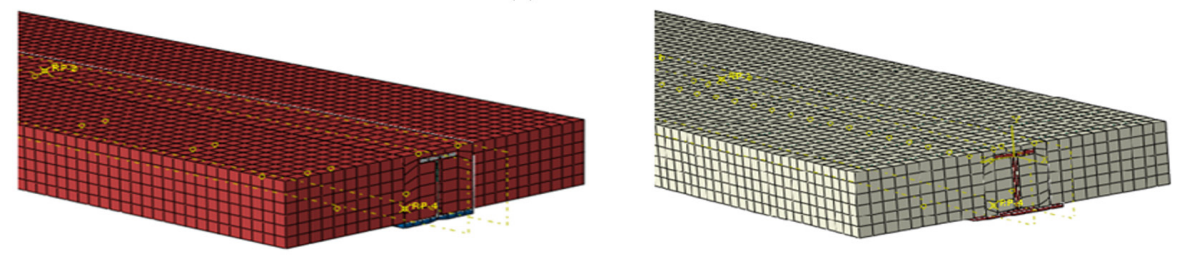

(b) Standardization

Figure 14. Model meshing.

\section{RESULTS AND DISCUSSIONS}

The analysis of the results was also divided into three parts. The first provides the calibration results, showing both models were validated according to experimental studies of Lawson et al. [4] and Hechler et al. [5]. Subsequently, a comparative analysis of the flexural behavior of the two typologies based on the results of standardization is presented.

The third part addresses the results of the parametric study and the influence of concrete strength, concrete topping above the steel beam, strength of the steel beams, and bottom flange thickness on the flexural behavior of the typologies.

\section{Models calibration}

In the calibration phase, simulations were performed until the numerical models could satisfactorily represent the experimental behavior. The properties of each experimental study were added to ABAQUS, and the parameters involved in the modelling that helped the definition of the structural behavior (e.g., CDP plasticity, aspects of contact interaction, and mesh of the components) were adjusted. The calibration process was conducted through a quantitative comparison between the mid-span load x mid-span deflection curves of the experimental studies and the numerical ones developed in the present study. Figure 15 displays the calibration graph of ASB.

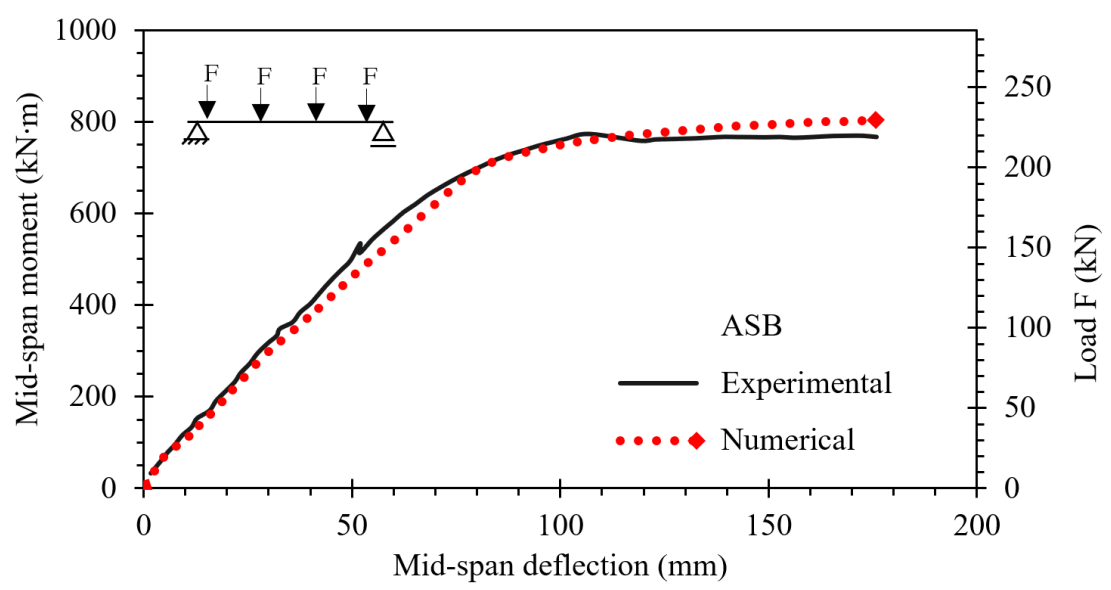

Figure 15. Asymmetric Slimflor Beam calibration.

The error related to the maximum load applied, defined by [(Fexp - Fnum)/Fexp], was used in the quantitative comparison between numerical and experimental curves. The ASB's calibration showed the results of the numerical model are compatible with the experimental ones, with an error of only $5.4 \%$ in the maximum load. In the linear phase, 
the numerical and experimental curves were almost superimposed. Failure modes were compared - a failure occurred with the crushing of the concrete, also identified in the numerical analysis, with longitudinal cracks at the top of the slab. Figure 16 shows the calibration results of Composite Slim-Floor Beam.

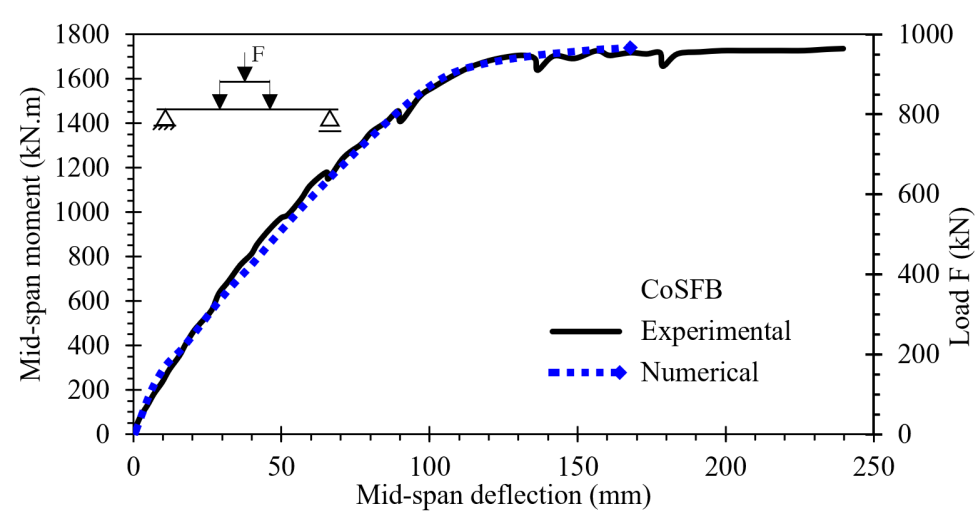

Figure 16. Composite Slim-Floor Beam calibration.

This typology showed an error of only $0.2 \%$ in the maximum applied load, and a behavior very similar to that of the experimental study. Both linear and nonlinear phases showed an excellent correlation between experimental and numerical results. The failure mode indicated in the experimental test was the crushing of concrete, also identified in the numerical analysis.

This model required a high computational cost and was unable to converge up to the prescribed displacement due to its geometric complexity, with many nonlinearities involved. Besides, convergence issues are also related to the limitation in the concrete damage plasticity model when type C3D8R finite elements are used [38]. Both calibrated numerical results showed good agreement with those from the experimental studies, therefore, the numerical models were reproducible and sufficiently precise to predict the flexural behavior of the studied typologies.

\section{Comparative analysis}

After calibration, the typologies were standardized according to the basic geometric dimensions and materials properties towards a reliable comparison between ASB and CoSFB. The aim of this phase was to understand the way the innovative characteristics of CoSFB, such as web openings, influence the flexural behavior of the system.

A limit deflection value was set for comparison and, due to the lack of a standard for slim floor tests, Eurocode 4 (2004) prescription for composite slabs was used. It establishes the load employed in analyses must be the highest value between the maximum applied load and the load corresponding to a L/50 deflection. The mid-span load $\mathrm{x}$ mid-span deflection curve was limited to $86 \mathrm{~mm}$ maximum deflection. Figure 17 shows the comparative results of the loaddeflection curves for ASB and CoSFB.

According to Figure 16, both typologies exhibited the same behavior in the linear elastic regime, up to the applied load of approximately $200 \mathrm{kN}$. After this point, the cracking of concrete caused a change in stiffness; CoSFB became more rigid than ASB and showed a higher computational cost due to the presence of openings in the profile, which imposes more nonlinearities.

The material properties, boundary and loading conditions were standardized in this phase. The main difference between ASB and CoSFB was the presence of small openings at the top of the profile web, which enables the passage of steel bars and concrete, thus ensuring the composite behavior and increasing both resistance capacity and stiffness of CoSFB. In comparison to ASB, which has no openings, CoSFB has higher strength and stiffness (Figure 17). Despite a lower strength value, ASB is more frequently used in slim floors and its construction has been consolidated. Its execution is simpler, and the asymmetric profile is more available on the international market.

The main stresses in concrete slabs and the stress based on the von Mises criterion for steel profiles were also analyzed (Figure 18). The grey zones in the slab are the tensioned ones, and the dark grey areas are those that reached compression stress higher than $f_{c}$, when the concrete enters plasticity, due to the high load in the composite slab. The crack pattern (red) due to tensile stresses (Damaget) is shown at the bottom of Figure 18a, and 18b. 


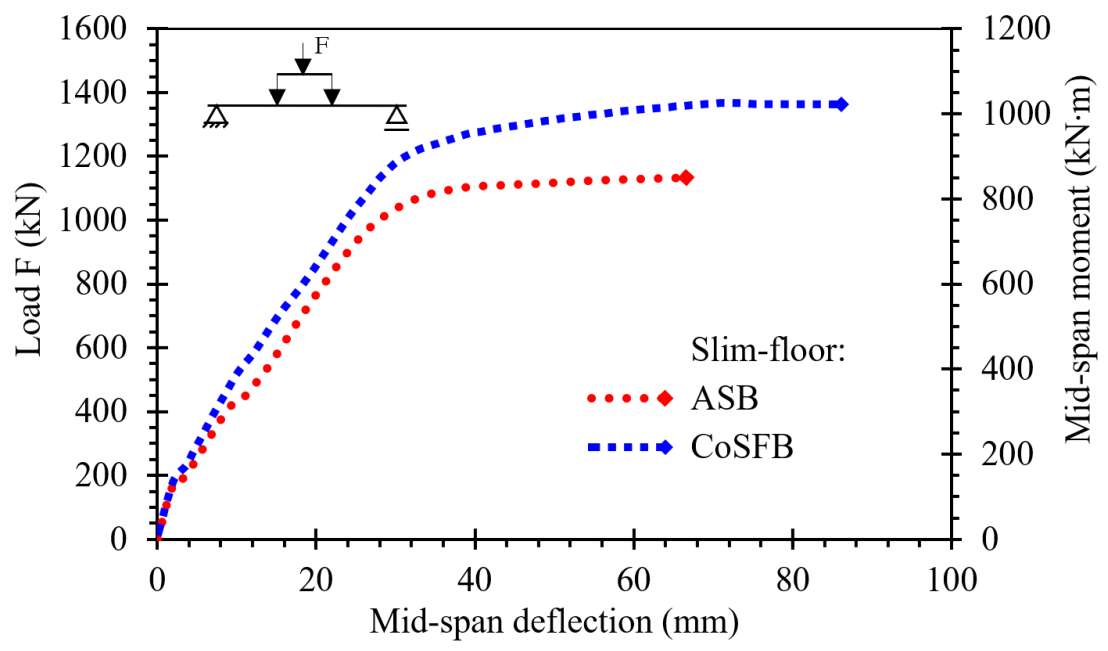

Figure 17. Comparative graph of flexural behavior.

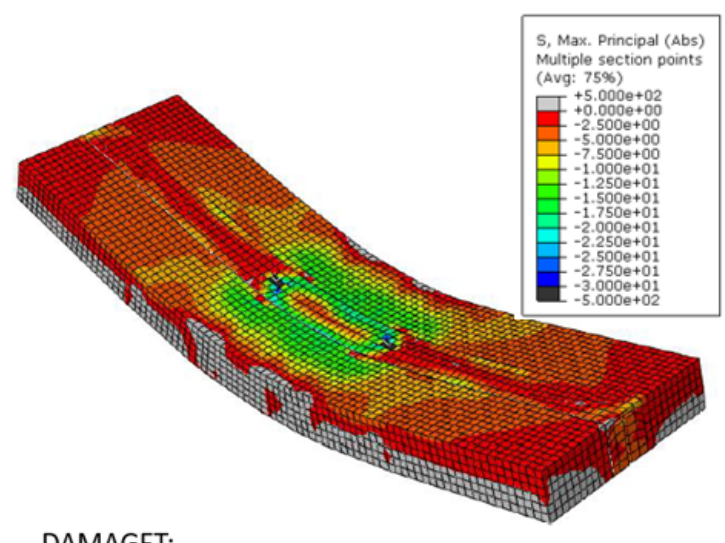

DAMAGET:

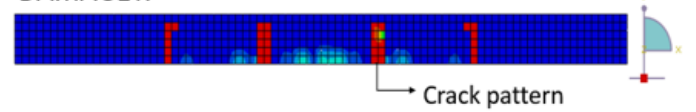

(a) Concrete stress - ASB
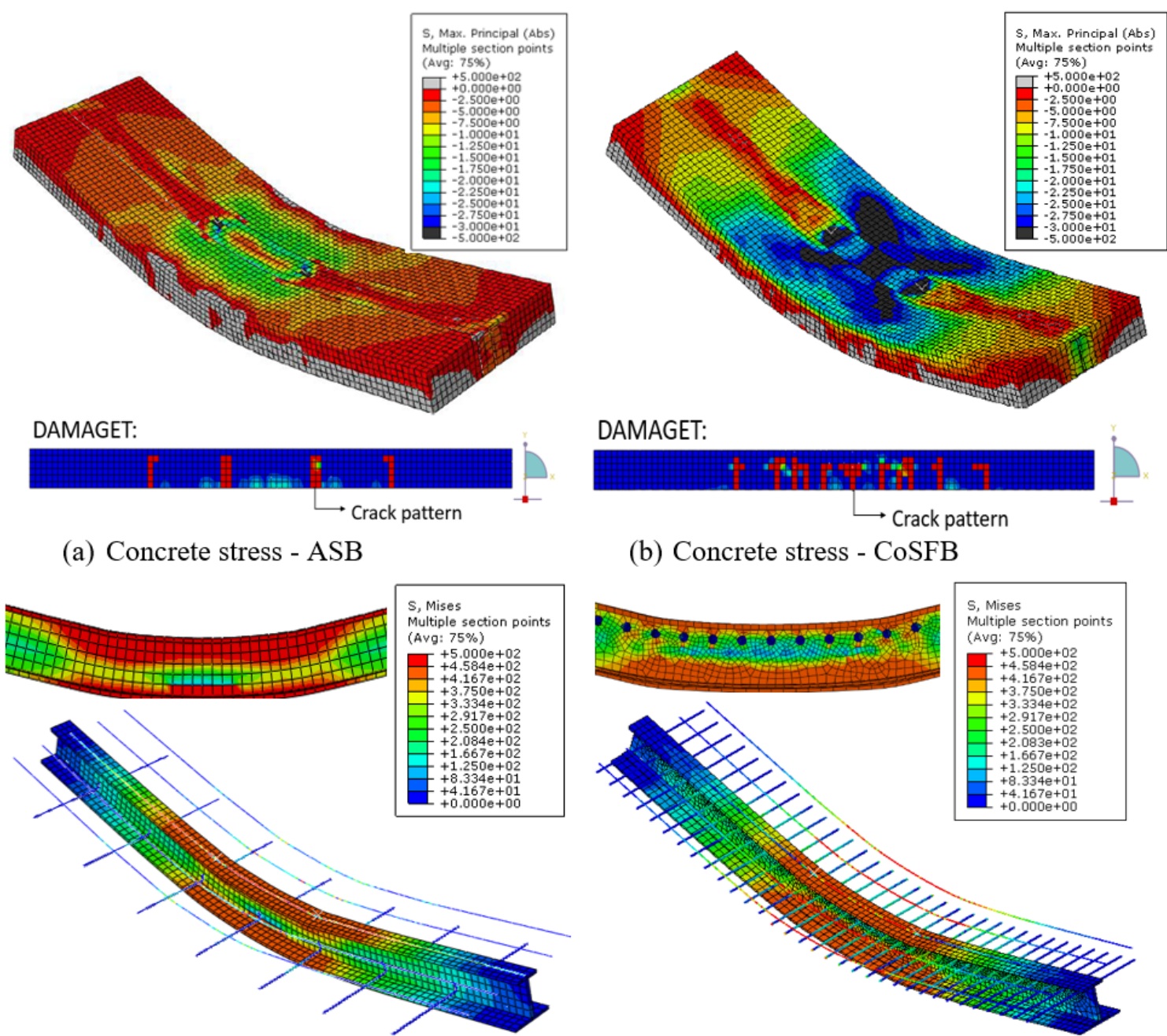

(b) Concrete stress - CoSFB

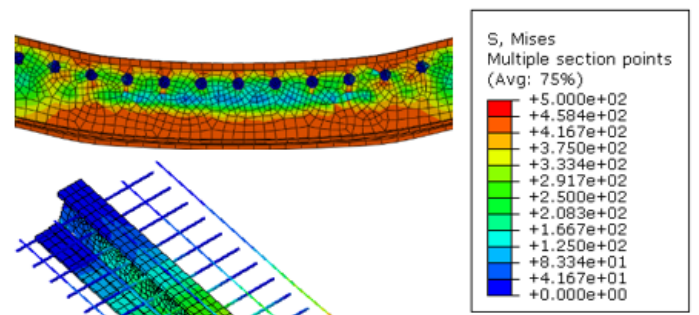

(c) Von Mises stress of steel beam - ASB

(d) Von Mises stress of steel beam - CoSFB

Figure 18. Stress of concrete and steel beam at the ultimate loads (measurements in MPa). 
In the final increment $(66.6 \mathrm{~mm})$, ASB was subjected to $1134 \mathrm{kN}$ and displayed characteristics of concrete crushing on top of the slab, mainly near the load application. It also showed vertical cracks related to tensile stresses at the bottom of the slab, near the load application points, highlighted in Figure 18a.

CoSFB was subjected to $1356 \mathrm{kN}$ for the same displacement of ASB $(66.6 \mathrm{~mm})$. The approximately $20 \%$ increase in the CoSFB load led to higher compression stresses in the upper central region of the slab, but with a smaller area of the tensioned concrete. However, this typology exhibited more vertical cracks than ASB, highlighted in Figure 18b. The failure mode was by concrete crushing, as in ASB.

The analysis of von Mises stresses in the profiles revealed the highest stresses are concentrated in the central part of the flanges. However, in ASB, the top flange was more requested, whereas CoSFB regularly distributed the tension between the two flanges and the plate. ASB web showed low-stress values. No stresses concentration was observed in the surroundings of CoSFB openings, since the concrete guarantees the necessary stiffness, highlighted in Figure 18d.

\section{Parametric study}

The influence of four parameters, namely concrete strength, concrete topping above the steel beam, strength of steel beams, and bottom flange thickness were chosen from a bibliographic review to be analyzed for both typologies. Two parameters, namely diameter of the openings and percentage of openings with bars crossing them were also analyzed for CoSFB. The parametric study focused on the mid-span load x mid-span deflection curve, and the standardized model was used as a reference.

\section{Concrete strength}

Three $\mathrm{f}_{\mathrm{c}}$ values, namely $20 \mathrm{MPa}, 30 \mathrm{MPa}$ (reference) and $40 \mathrm{MPa}$, were analyzed. Figure 19 shows the graphs for each typology.

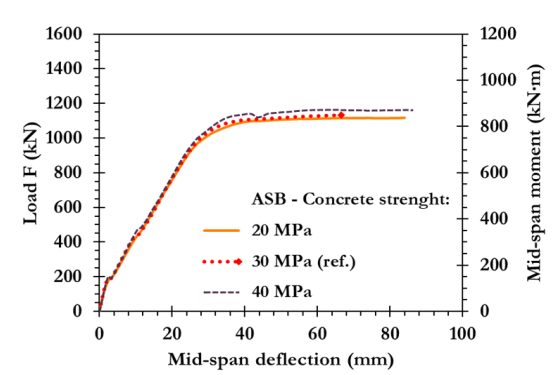

a) ASB

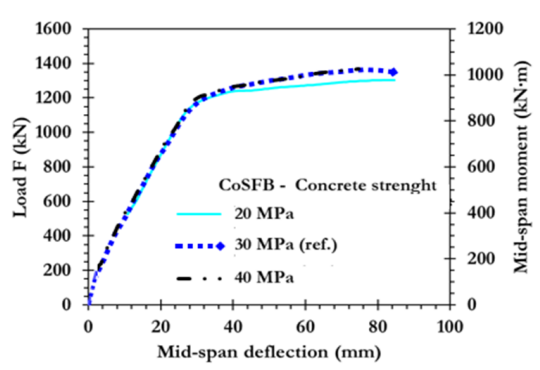

b) CoSFB

Figure 19. Load-deflection curve - Concrete strength.

An increase in concrete strength increased the maximum strength without affecting the stiffness of the structure. This parameter does not exert a significant influence on the flexural behavior of the typologies; however, CoSFB was more affected than ASB.

\section{Concrete topping above the steel beam}

Three analyses - with no concrete topping, with $23 \mathrm{~mm}$ concrete topping (reference), and with $46 \mathrm{~mm}$ concrete topping - assessed the influence of the concrete topping above the steel beam on the slim floor. Mid-span load $\mathrm{x}$ midspan deflection curves were obtained for each typology, as shown in Figure 20. 


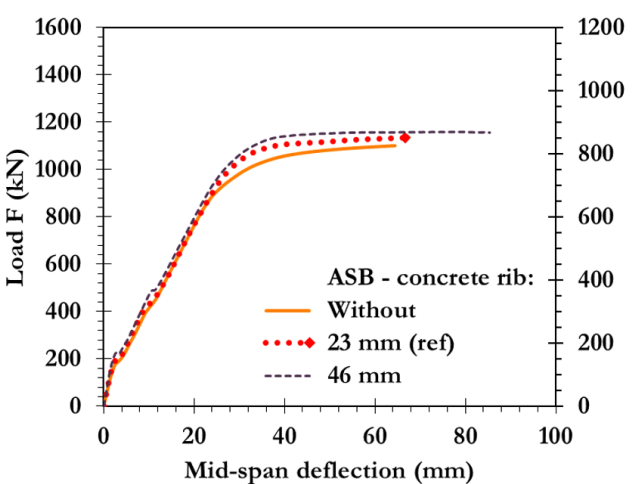

a) ASB

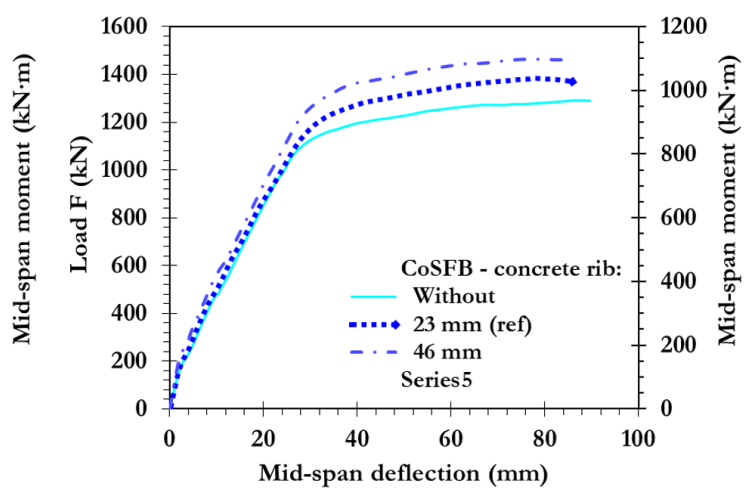

b) CoSFB

Figure 20. Load-deflection curve - Concrete topping above the steel beam.

Likewise, this parameter was not significant, especially in ASB, since it did not influence stiffness, and the resistance capacity was slightly increased. However, it was more influential than the previous one.

\section{Strength of steel beams}

Three values of yield strength, namely $380 \mathrm{MPa}, 430 \mathrm{MPa}$ (reference) and $480 \mathrm{MPa}$, were chosen for the evaluation of the influence of strength of steel beams, and the ultimate strength was set at $550 \mathrm{MPa}$. Figure 21 shows the behavior of the typologies.

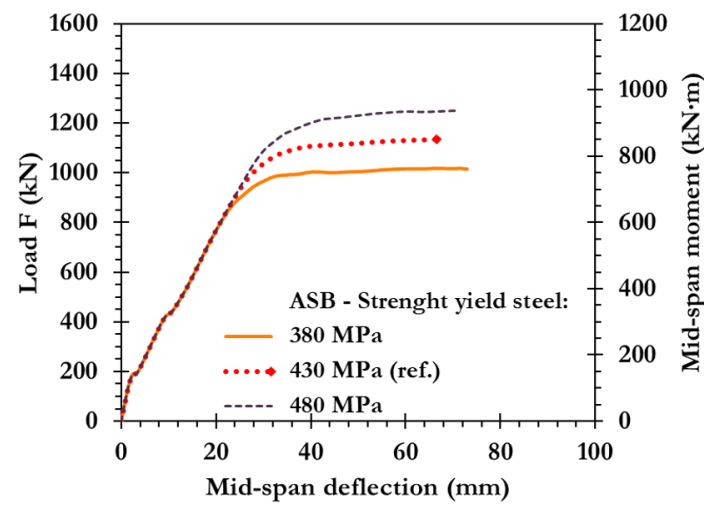

a) ASB

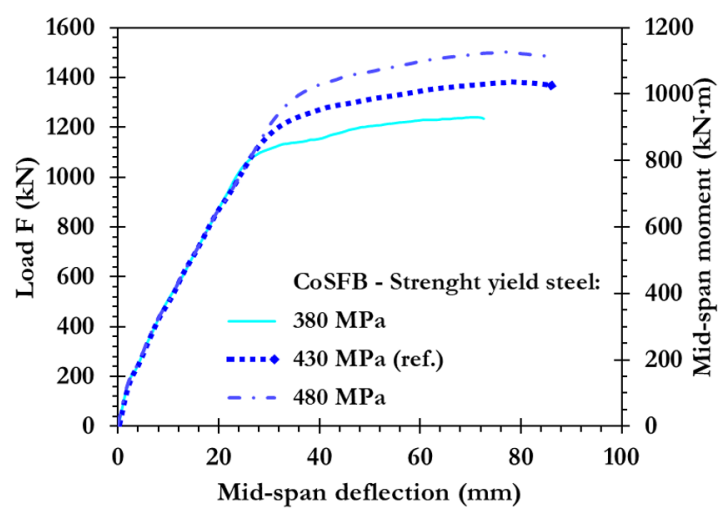

b) CoSFB

Figure 21. Load-deflection curve - Strength of steel beams.

The two typologies exhibited very similar behaviors. The strength of the profile considerably influenced the resistance capacity, increasing with the increase in the yield strength. However, stiffness was not affected.

\section{Bottom flange thickness}

Three cases for the bottom flange thickness, namely $11.5 \mathrm{~mm}, 23 \mathrm{~mm}$ (reference) and $34.5 \mathrm{~mm}$, were verified. Figure 22 shows the behavior of the two typologies. 


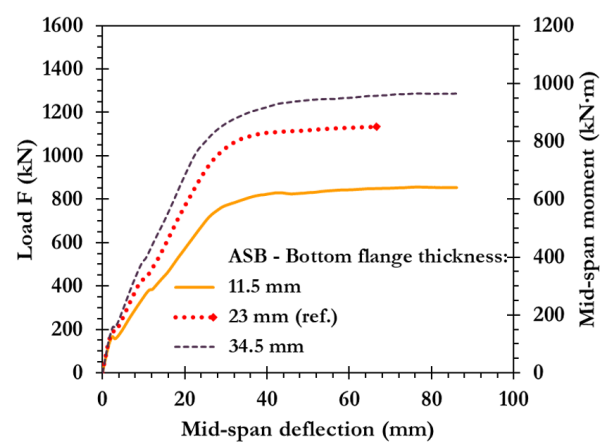

a) $\mathrm{ASB}$

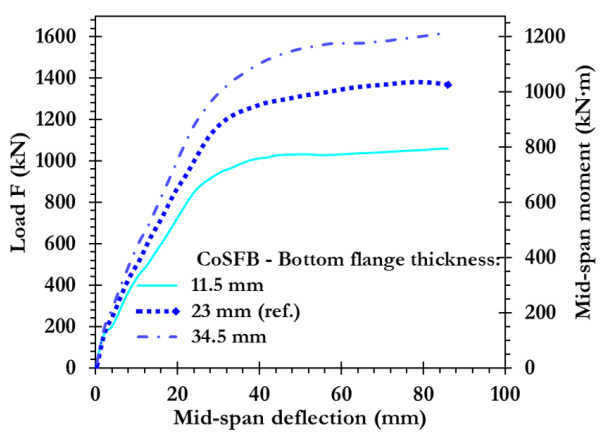

b) $\mathrm{CoSFB}$

Figure 22. Load-deflection curve - Bottom flange thickness.

For CoSFB, the two thicknesses whose sum composes it proportionally decreased or increased for the analysis.

A variation in this parameter, which was the most influential in the flexural behavior of the typologies, showed an increase in the bottom flange thickness considerably increases both resistance capacity and stiffness.

\section{Analyses of CoSFB openings}

CoSFB differs from ASB mainly due to the presence of web openings, which enable the passage of rebars. Two parametric studies conducted analyzed the behavior of such openings. In the first, the diameter of the openings was varied, analyzing the original size $(40 \mathrm{~mm})$, a larger diameter $(80 \mathrm{~mm})$ and a smaller diameter $(20 \mathrm{~mm})$, and the second focused on the percentage of openings with bars crossing them. The following three cases were analyzed: " $100 \%$ ", which represents the system with the rebars passing through all openings, "50\%", with half the openings crossed by rebars, and " $0 \%$ ", with no bar passing through the openings. Figure 23 shows the behavior for each analysis.

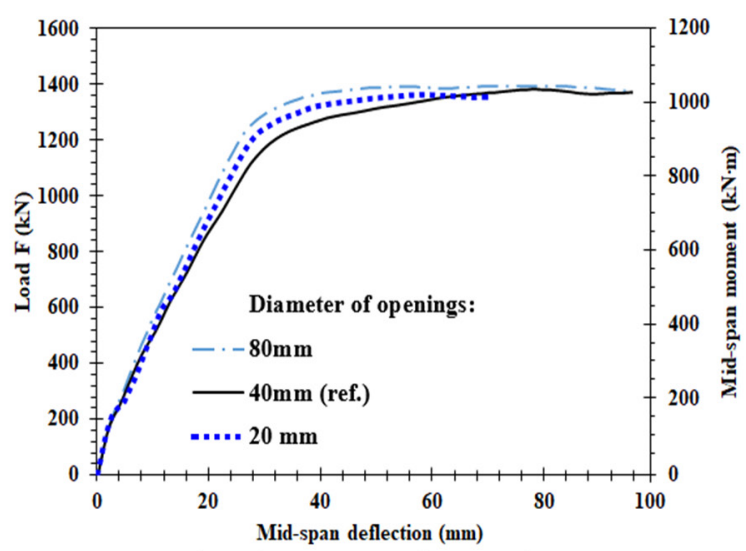

a) Diameter of openings

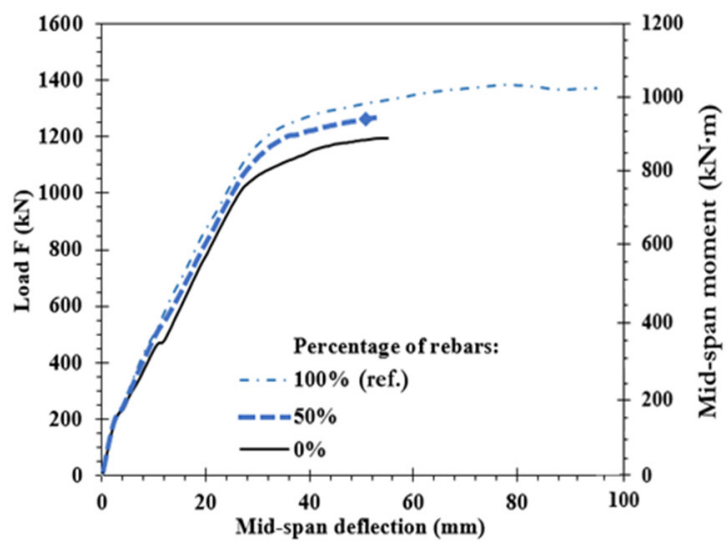

b) Rebars

Figure 23. Load-deflection curve - Analyses of CoSFB openings.

In the first analysis, the diameter of the openings influenced both initial resistance and stiffness of the structure. The $40 \mathrm{~mm}$ opening system showed lower initial resistance; however, it increased and reached high values at the end of the analysis. When 20 and $80 \mathrm{~mm}$ diameters were used, higher initial resistance was observed; however, convergence for greater displacements of the $20 \mathrm{~mm}$ system was hampered by the concrete high compression stresses in the openings, indicating crushing of concrete. Therefore, further analyses are necessary for the establishment of a proper diameter of the system. 
The second analysis revealed a reduction in the percentage of rebars passing through the openings decreases the stiffness and capacity of the system. The convergence of the simulation was also affected by the reduction in the number of rebars, indicating a faster degradation of the structure with fewer bars.

\section{CONCLUSIONS}

This article has addressed numerical studies on the flexural performance of two different typologies, namely ASB and CoSFB composite beams used in slim-floor, and the results have led to the following conclusions:

- Calibration phase: the numerical simulation reproduced the behavior of the experimental models, and, therefore, can predict their flexural performance. Small divergences between experimental and numerical results are due to limitations in the simulation related to differences between the real properties and those estimated in the numerical model, and simplifications adopted.

- Comparative study: the comparison phase revealed ABS is less stiff and resistant than CoSFB and showed high plastic deformations and a large region of slab tensioned at the end of the simulation. CoSFB showed higher compression stresses, indicating crushing of the concrete at the end of the simulation, with a smaller region of concrete under tension.

- Parametric analysis: two parameters related to concrete (concrete strength and concrete topping above the steel beam) and two others related to the steel profile (strength steel and bottom flange profile thickness) were varied for both typologies. Those in the profile significantly increased resistance and rigidity. The variation in the lower flange thickness was the most influential, whereas concrete strength exerted the lowest influence on the typologies. For CoSFB, analyses of the diameter of the openings and the percentage of openings with bars crossing them revealed the passage of steel bars through the openings improves the structural behavior. Further analyses of the diameter of the openings are necessary for the establishment of a proper diameter of the system and consequent improvement in the behavior of the structure with no concrete crushing.

This study achieved its objective of comparing two typologies of slim floor, i.e., ASB and CoSFB, and performing parametric analyses, with satisfactory and applicable results. It has, therefore, contributed to the dissemination of knowledge on slim floor, presenting some typologies, with important information about ASB and CoSFB and their flexural behaviors.

In practical terms, the choice of a typology must still take into account aspects of technical and economic feasibility. Topics such as labor, ease of acquisition and assembly, logistics, speed of construction and architectural impositions must be considered. Moreover, the capacity of each typology can be improved with the use of specific slabs (e.g., steel deck and hollow-core slabs). Such analyses are suggested for future studies.

\section{ACKNOWLEDGEMENTS}

The authors acknowledge the Conselho Nacional de Desenvolvimento Científico e Tecnológico (CNPq) for the financial support given to this research. The study was also financed by the Coordenação de Aperfeiçoamento de Pessoal de Nível Superior - Brasil (CAPES) - Finance Code 001 and grant \#2019/03513-5, São Paulo Research Foundation (FAPESP).

\section{REFERENCES}

[1] M. Malite, "Sobre o cálculo de vigas mistas aço-concreto: ênfase em edifícios,” M.S. thesis, Dept. Struct. Eng., Univ. São Paulo, São Carlos, 1990.

[2] S. De Nardin and A. L. H. C. El Debs, "Avaliação da influência da posição dos conectores de cisalhamento no comportamento de vigas mistas parcialmente revestidas," Rev. Esc. Minas, vol. 61, no. 2, pp. 239-247, 2008., http://dx.doi.org/10.1590/S037044672008000200019.

[3] T. M. Borghi, "Contribuição ao estudo do piso misto de pequena altura: análise numérica das tipologias,” M.S. thesis, Dept. Struct. Eng., Univ. São Paulo, São Carlos, 2020.

[4] R. M. Lawson, D. L. Mullet, and J. W. Rackham, Design of Asymmetric Slimflor Beams Using Deep Composite Decking (SCI Publication P175). Ascot, UK: The Steel Constr. Inst., 1997.

[5] O. Hechler, M. Braun, R. Obiala, U. Kuhlmann, F. Eggert, and G. Hauf, "CoSFB: composite slim-floor beam: experimental test campaign and evaluation,” in Proc. VII Int. Conf. Composite Constr. Steel Concr., 2016, pp. 158-172. [Online]. Available: https://ascelibrary.org/doi/10.1061/9780784479735.013

[6] Tata Steel. https://www.tatasteelconstruction.com/en_GB/tata-steel-case-studies/other/Chasse-Church (accessed June 26, 2020). 
[7] ArcelorMittal, Slim Floor - an Innovative Concept for Floors. Luxemburgo, 2017.

[8] D. L. Mullet, Slim Floor Design and Construction (SCI Publication P110). Ascot, UK: The Steel Constr. Inst., 1992.

[9] D. L. Mullet and R. M. Lawson, Slim floor Construction using Deep Decking (SCI Publication P127). Ascot, UK: The Steel Constr. Inst., 1993.

[10] British Standard, Structural Use of Steelwork in Buildings - Part 3: Code of Practice for Design of Simple and Continuous Composite Beams, BS5950-3, 1982.

[11] C. G. Bailey, "The behaviour of asymmetric slim floor steel beams in fire," J. Construct. Steel Res., vol. 50, no. 3, pp. 235-257, 1999, http://dx.doi.org/10.1016/S0143-974X(98)00247-8.

[12] P. Mäkeläinen and Z. Ma, "Fire resistance of composite slim floor beams," J. Construct. Steel Res., vol. 54, no. 3, pp. 345-363, 2000, http://dx.doi.org/10.1016/S0143-974X(99)00059-0.

[13] J. L. R. Paes, “Aportaciones al análisis del comportamiento estructural de sistemas de forjados mixtos tipo "Slim floor,” Ph.D. dissertation, Dept. Constr. Eng., Univ. Politéc. Catalunha, Barcelona, Spain, 2003.

[14] M. V. Leskelä and J. Hopia, Steel Sections for Composite Shallow Floors. Report RLT 0053E. Oulu, Finland: Univ. Oulu, Struct. Eng. Lab., 2000.

[15] J. W. Rackham, S. J. Hicks, and G. M. Newman, Design of asymmetric slimflor beams with precast concrete slabs. The Steel Construction Institute, 2006.

[16] I. M. Ahmed and K. D. Tsavdaridis, "The evolution of composite flooring systems: applications, testing, modelling and Eurocode design approaches," J. Construct. Steel Res., vol. 155, pp. 286-300, Apr 2019, http://dx.doi.org/10.1016/j.jcsr.2019.01.007.

[17] M. O. Barros, “Análise e dimensionamento de pavimentos mistos slim floor,” M.S. thesis, Univ. Nova Lisboa, Lisbon, 2011.

[18] M. Braun et al., "Experimentelle Untersuchungen von Slim-Floor-Trägern in Verbundbauweise," Stahlbau, vol. 83, no. 10, pp. 741749, Oct 2014, http://dx.doi.org/10.1002/stab.201410204.

[19] T. Sheehan, X. Dai, J. Yang, K. Zhou, and D. Lam, "Flexural behaviour of composite slim floor beams," Structures, vol. 21, pp. 2232, Oct 2019, http://dx.doi.org/10.1016/j.istruc.2019.06.021.

[20] N. Baldassino, G. Roverso, G. Ranzi, and R. Zandonini, "Service and ultimate behaviour of slim floor beams: an experimental study," Structures, vol. 17, pp. 74-86, 2019, http://dx.doi.org/10.1016/j.istruc.2018.10.001.

[21] Y. K. Ju, D. Kim, and S. Kim, "Experimental assessment of the shear strength of an asymmetric steel composite beam with web openings," Can. J. Civ. Eng., vol. 32, no. 2, pp. 314-328, 2005, http://dx.doi.org/10.1139/104-094.

[22] M. V. Leskela, S. Peltonen, A. Iliopoulos, and P. Kiriakopoulos, "Numerical and experimental investigations on the vertical shear resistance of boxed steel cross-sections with concrete infill (Deltabeams)," in EUROSTEEL 2014, Naples, Italy, 2014.

[23] D. Lam, X. Dai, U. Kuhlmann, J. Raichle, and M. Braun, "Slim-floor construction - design for ultimate limit state," Steel Constr., vol. 8, no. 2, pp. 79-84, 2015, http://dx.doi.org/10.1002/stco.201510019.

[24] B. Y. Huo and C. A. D’Mello, "Shear transferring mechanisms in a composite shallow cellular floor beam with web openings," Structures, vol. 9, pp. 134-146, 2017, http://dx.doi.org/10.1016/j.istruc.2016.11.003.

[25] S. Chen and T. Limazie, "Composite slim floor beams with innovative shear connections," Proc. Inst. Civ. Eng., Struct. Build., vol. 171, no. 1, pp. 29-37, 2017., http://dx.doi.org/10.1680/jstbu.16.00171.

[26] F. M. Rocha, "Modelos numéricos de vigas mistas de aço e concreto pertencentes a sistemas de pisos mistos de pequena altura em situação de incêndio,” M.S. thesis, Dept. Struct. Eng., Univ. São Paulo, São Carlos, 2012.

[27] C. Maraveas, T. Swailes, and Y. Wang, "A detailed methodology for the finite element analysis of asymmetric slim floor beams in fire," Steel Constr., vol. 5, no. 3, pp. 191-198, Aug 2012, http://dx.doi.org/10.1002/stco.201210024.

[28] T. Limazie and S. Chen, "FE modeling and numerical investigation of shallow cellular composite floor beams," J. Construct. Steel Res., vol. 119, pp. 190-201, 2016., http://dx.doi.org/10.1016/j.jcsr.2015.12.022.

[29] R. F. F. Kochem and S. De Nardin, "Numerical model of beam-to-column composite connection between slim floor system and composite column," Rev. IBRACON Estrut. Mater., vol. 13, no. 2, pp. 348-379, Apr 2020, http://dx.doi.org/10.1590/s198341952020000200009.

[30] V. C. Minhaneli, “Avaliação do comportamento estrutural de vigas mistas para sistemas de piso slim floor formadas por perfis de aço com grandes aberturas na alma,” M.S. thesis, Fed. Univ. Viçosa, Viçosa, 2018.

[31] L. C. Soares, “Análise via método dos elementos finitos de pisos mistos de pequena altura - Slim Floor,” M.S. thesis, Fed. Univ. Ouro Preto, Ouro Preto, 2012.

[32] A. N. Sherbourne and M. R. Bahaari, "M. R. Bahaari, 3D simulation of bolted connections to unstiffened columns - I. T-stub connections," J. Construct. Steel Res., vol. 40, no. 3, pp. 169-187, 1996, http://dx.doi.org/10.1016/S0143-974X(96)00048-X.

[33] P. O. Ribeiro, G. M. S. Gidrão, L. V. Vareda, R. Carrazedo, and M. Malite, "Numerical and experimental study of concrete I-beam subjected to bending test with cyclic load," Lat. Am. J. Solids Struct., vol. 17, no. 3, e266, 2020.

[34] D. J. Carreira and K. Chu, "Stress-strain relationship for plain concrete in compression," ACI J., vol. 82, pp. 797-804, 1985. 
[35] M. A. Polak and A. S. Genikomsou, "Finite element analysis of punching shear of concrete slabs using damaged plasticity model in ABAQUS," Eng. Struct., vol. 98, pp. 38-48, 2015., http://dx.doi.org/10.1016/j.engstruct.2015.04.016.

[36] V. Birtel and P. Mark, "Parameterised finite element modelling of RC beam shear failure," in Proc. 19th Annu. Int. ABAQUS Users' Conf., Boston, 2006, pp. 95-108.

[37] M. Pavlović, Z. Marković, M. Veljković, and D. Buđevac, "Bolted shear connectors vs. headed studs behaviour in push-out tests," J. Construct. Steel Res., vol. 88, pp. 134-149, 2013, http://dx.doi.org/10.1016/j.jcsr.2013.05.003.

[38] L. D. Kirchhof, "Uma contribuição ao estudo de vigas mistas aço-concreto simplesmente apoiadas em temperatura ambiente e em situação de incêndio,” M.S. thesis, Dept. Struct. Eng., Univ. São Paulo, São Carlos, 2004.

Author contributions: TMB: conceptualization, methodology, numerical analysis, writing, review; LAMO: conceptualization, writing, review; ALHCED: supervision, text review.

Editors: Bruno Briseghella, Guilherme Aris Parsekian. 